\title{
If a Poet Could Talk We Could Not Understand Him
}

\author{
for Charles Bernstein
}

This is a found text useless words talking sounds a stone taking shape by itself unlike the divine clock clicking your cobblestones hosteron proteron contradictions interdicted silent intentions bestial thoughts a gravity of stones filling your pockets so many groans applying their pleasure lidless eyes impinging as if to see better not to look rattle (pause) rattle old bones cluster and start their run ten toes steadfast faster still if possible a stone's throw alone trips the trope musters your mustard one pebble two two pebbles three failing to pass a lonely aesthete sounding his symbols category mistakes versified fakes a transcendental appetite forging its experience lines of dead argument dissymmetrical forms chance operations Geistesgeschichte biting its tail sarcophagia encyclopedic memories housed in small letters insufficiency of reasons Leibniz his alphabet seeing the goddess naked freezes fingers sounds the key speedy metricals early terminals (anacoluthoniclone) just call him Charles magister ars inveniendi accidentally unearthing a large loose locution whose grammar held us captive 